UDC $94(4)+(442) 63-6$

DONAJ LUKASH,

Adam Mickiewicz University in Poznań (Poland),

e-mail: lukasz.donaj@amu.edu.pl, ORCID 0000-0002-7720-1260

ZAVADSKYI VITALIY,

Borys Grinchenko Kyiv Uviversity (Ukraine),

e-mail:v.zavadskyi@kubg.edu.ua, ORCID 0000-0002-0384-5979

\title{
15 YEARS OF THE BALTIC STATES' MEMBERSHIP IN THE EU: PROBLEMS, PROSPECTS AND EXPERIENCE FOR UKRAINE
}

The article highlights the key provisions of the study of the results of the Baltic States' full membership in the European Union. Analyzing a geopolitical dimension of the European choice, the authors present a brief discourse of challenges which arose during the restoration of independence of Latvia, Lithuania and Estonia. The factors of the European choice of the above countries, which comprised security, economic and social dimensions, are explored.

The security factor of the European vector of politics was actualized in the desire of political elites to withdraw the countries from the sphere of influence of Russia. In terms of economics, the countries sought reorientation of their economies to Western markets and incorporation into the architecture of trade relations of developed countries of the European Union.

It is pointed out that owing to the Euro-Atlantic foreign policy vector and strict fulfillment of membership criteria, the Baltic States acquired access to preferential lending and assistance programs to candidate countries and managed to form one of the most attractive investment climates in Eastern Europe.

With the help of the World Bank data bases, the Eurostat resource and analytical materials of the leading audit company KPMG, there are key economic indicators analyzed: the GDP dynamics (by PPP) compared to other countries of Central and Eastern Europe as well as wage and retirement benefit levels. The examination of EU membership economic gains is supplemented with an analysis of the GDP structure and exploration of the industry specification.

Some losses associated with the European integration process are also identified, namely: significant reduction of industrial production, unprofitability of agriculture and emigration of the population aged 25 to 35 years.

The residents' attitude to the EU membership is looked into, based on results of annual surveys of the Eurobarometer European Service. It is found that a positive attitude of the residents of Latvia, Lithuania and Estonia in 2018 did not actually change versus to 2004. Further, the charts presented in the article allow to establish that the level of Euroscepticism in the above countries did not change significantly, compared to the first year of the EU membership.

The authors propose some algorithms for taking account of the experience of the Baltic States on the way to a full membership by Ukraine.

Key words: Baltic States; EU; results; membership; Ukraine; experience.

Problem definition. The major expansion of the European Union in 2004 became a unique implementation example of ambitious globalization projects in Europe. For the first time, the EU included the former Soviet Republics of Latvia, Lithuania and Estonia - the countries which shortly after restoring their independence had managed to meet the membership criteria and demonstrated rapid paces of changes.

The example of the Baltic States is interesting in the historical context in terms of transit and architecture of the modern political profile of Europe.

The experience of the Baltic States is in many ways useful for Ukraine as an Associate Member State of the European Union. Our State needs to prepare and test some algorithms for operation of numerous segments of the infrastructure in order to develop a successful strategy of synchronization with United Europe. An analysis of positive experience and consideration of negative trends in the European integration progress of Latvia, Lithuania and Estonia in the historical, political and economic dimensions serves an additional tool for adjusting the Ukrainian state policy of meeting the EU requirements.

Analysis of main publications. Comprehensive coverage of the issues presented in the article in Ukrainian historical studies has not yet become the subject of special research. Results of the integration in terms of security were considered in works by S.V. Bilonozhko (2015) and O.A. Paliy (2002). Economic, partially social gains and 
losses as a result of European integration were looked into in works by O. V. Kokorev (2016). An animated discussion of European integration gains and losses broke out in scientific works by foreign researchers. Specifically, the Russian scientist V. V. Vorotnikov (2014) negatively assesses the European integration processes of the above countries. Gunta Pastore upholds an opposite view, emphasizing positive results and achievements (2011).

Purpose of the article is to examine the main outcomes, challenges, losses and prospects of the membership of the above countries in the European Union.

Presentation of the main material. After the disintegration of the Soviet Union, the Baltic States faced a whole range of challenges related to the development of a foreign policy strategy, reorientation of the economy and formation of new values in society. All transformations initiated by the governments were carried out in a rather complex external environment. For a long time, a part of the Russian Federation's politicum had been advancing quite aggressive slogans associated with a threat to independence and territorial integrity. Especially acute and topical was the factor of the Kaliningrad Region which housed a significant part of the Russian troops and Navy.

To assess the global level of results of European choice, we firstly need to understand the prospects that were open at the time of the restoration of independence. The choice of a geopolitical vector was extremely difficult and required maximum flexibility of political elites, since in the early 1990s the factor of Russian influence, supplemented with a military factor, acted as a serious obstacle to European integration. It is worth noting that mentality and values of the majority of the local population were closer to Europe than to the Eastern neighbors. Further, a part of the population, especially those born in the 19301940 s, considered Russia mostly as an aggressive neighbor. The European vector was therefore mentally and value-wise perceived as a "return" to the Western world. The purposeful and consistent Euro-Atlantic foreign policy of the Baltic States made it possible to get rid of the Eastern gravity vector. As early as in the mid-1990s, the risks associated with the breaking of economic relations were completely offset by lending programs of the EBRD and the IMF. Naturally, the credit programs put forward strict demands that led to extremely negative consequences in the economy. The prevailing view in society of the day however was that independence was of high price. In addition to lending, the economies of the Baltic States after the latter had become Associate Members of the EU, obtained significant support from United Europe in the form of assistance programs (PHARE, ISPA, SAPPARD) (Zavadsky, 2008: 66-67).

At the time of the restoration of independence, the economies of Latvia, Lithuania and Estonia were mainly focused on the market and raw material base of the former Soviet Republics. The breaking of economic ties and a general decline in demand for Baltic goods became a serious test for many industries. In the early 1990s, most industrial equipment was already technologically outdated and required considerable investment. Such measures as several waves of privatization, free sale of land and recruitment of investment became the sources of financial system stabilization.

The highest rates of inflation in the three countries were observed in 1992-1993. For example, the inflation in 1992 reached 900 to $1,000 \%$ per year (Agenda 2000, 1997: 81-82).

The development of a new foreign policy vector in the wake of Euro-Atlantic integration greatly contributed to the investment attractiveness of the national economies. The authors' study into the correlation of European choice with volumes of investment in the 1990s allows to state that after a clear identification of external cues, European countries began to invest much more funds (Zavadsky, 2008: 67-68).

The process of acquiring a full EU membership and access to funding programmes enabled the countries to overcome negative effects of the transition period within five years. In addition, European integration became a major catalyst for the economic, political and social development of Latvia, Lithuania and Estonia. This thesis is supported by meeting the EU full membership criteria which include the development of a market economy, ensuring the operation of democratic institutions and the capability to adapt the legal framework to European standards.

14 years have passed since the Baltic States gained their full membership. To understand the development level of the above countries as full members, we will examine the dynamics of the key economic indicators in comparison with the countries of Central and Eastern Europe, which joined the EU also in 2004.

The GDP per capita in Latvia, Lithuania and Estonia in 2016-2018 shows stable annual growth rates of US Dollar 2,000 as the average. Compared to other EU Member

Table 1. GDP dynamics of the Baltic States (by the purchasing power parity) versus other countries of Europe (in US Dollars)

\begin{tabular}{|l|c|c|c|}
\hline \multicolumn{1}{|c|}{ Country/Year } & $\mathbf{2 0 1 6}$ & $\mathbf{2 0 1 7}$ & $\mathbf{2 0 1 8}$ \\
\hline EU (mean indicator) & 39,486 & 41,175 & 42,250 \\
\hline Czechia & 33,529 & 35,512 & 37,423 \\
\hline Slovakia & 31,403 & 33,025 & 35,099 \\
\hline Lithuania & 30,097 & 32,299 & 34,829 \\
\hline Estonia & 29,685 & 31,750 & 33,553 \\
\hline Poland & 27,741 & 29,521 & 31,647 \\
\hline Hungary & 27,770 & 29,474 & 31,561 \\
\hline Latvia & 25,725 & 27,644 & 34,829 \\
\hline Georgia & 10,053 & 10,747 & 11,600 \\
\hline Ukraine & 8,331 & 8,713 & 9,182 \\
\hline Moldova & 5,340 & 5,661 & 7,104 \\
\hline
\end{tabular}

\footnotetext{
1 Developed by the authors, based on: List of European countries by GDP per capita. URL: http://statisticstimes.com/economy/europeancountries-by-gdp-per-capita.php (Accessed: 21.11.2018)
} 
States of Central and Eastern Europe, the indicators of the three Republics are almost at the same level. Georgia, Ukraine and Moldova demonstrate the lowest rates in the group of the compared countries. However, the group of Central and Eastern European countries still falls short of the average GDP of the European Union.

Let us look into the structure of the economies of the countries in question. For more thorough understanding of the whole picture, it is worth mentioning that a rational model of economy has been searched for since the early 2000 s. As the resource base and lack of cheap energy did not allow to rapidly develop the heavy industry while competitive advantages of more technologically advanced economies (primarily the countries of Scandinavia and Western Europe) gave no way for promotion of high-tech industries, there was a development scenario of the transport industry, banking and service sector implemented. The economy structure of the three countries is dominated by the service sector ( $70 \%$ on the average), the processing industry accounts for $25 \%$ and agriculture for $5 \%$ (The World Factbook... URL)

The non-production specification for the most part has become the main trend in the economic development of the Baltic States. The economy sectors which secure a significant share of the GDP formation are not related to the production sphere. The vast majority of industries produce goods or services with a low value added level, which in turn has led to low wages, compared to the European Union countries. For example, according to the World Bank, the average wages in the Baltic States (including taxes) in 2018 amounted to Euro 720, whereas those in the EU came to Euro 1,400 (Wage and salaried workers...URL).

As a result of the changes associated with the economy restructuring during the European integration progress, agriculture in the Baltic States has lost its weight in the GDP structure. In the context of the free trade zone, low efficiency and noncompetitiveness of the industry, production volumes have significantly dropped. The EU single market and agricultural specification of some regions of the Member States, featuring a high efficiency level, make the agricultural production in the Baltic States unprofitable. The basic production is concentrated at small farms which products are consumed mainly in the domestic market.

The closure of the Ignalina Nuclear Power Plant in Lithuania, which supplied inexpensive energy to all the three countries, became one of negative phenomena. The closure of the Plant was an EU demand motivated by the environmental danger of the facility.

Successful infrastructure projects include the development of a transport corridor that links Baltic States' ports to Central and Eastern Europe. The ports of Latvia, Lithuania and Estonia account for $11 \%$ of maritime traffic in the EU.

In addition to the above areas, the Baltic States create the most attractive environment for investors in the small and medium business sector. According to the World Bank, in 2010-2018 the investment climate tripled compared to the period from 2005 to 2009 . Policies of the governments of Latvia, Lithuania and Estonia are aimed at efficient recruitment of foreign capital. This thesis is implemented through liberal conditions of real property and land acquisition by foreigners, simplified procedures for admittance to citizenship, subject to investments and development of business projects (Investment in Baltic States...URL).
Owing to the above economic specification, the economy of the Baltic States greatly depends on fluctuations of global trade trends and solvency of the local population. The service sector, transport and financial services are all extremely vulnerable during the industry crisis.

According to annual accounts of the international auditing company KPMG, the investment climate and tax system in the Baltic States in 2019 are the most attractive among the Central and Eastern European countries (Investment in Baltic States...URL).

The opening of the borders with EU countries had a significant impact on the outflow of the able-bodied population from the countries in question after 2004. Since the liberalization of the visa regime with EU countries, there has been a significant increase in emigration rates observed. The 25-35 age group was particularly active in this regard. According to the Eurostat European Statistics Service, 28 thousand people of the above age on the average annually leave each Baltic country for working in the EU (Total number of long-term emigrants...URL).

According to Eurostat's annual statistical reports, such processes are also typical of more successful EU countries. In general, the flow of able-bodied citizens in search for jobs to European countries has been a steady trend over the recent 30 years. The outflow of population from the Baltic States is largely related to the expansion of training opportunities in the EU.

A significant part of Eurosceptics in the Baltic States consider the above factor perhaps the most important loss related to European integration. It is worth mentioning that migration processes have been typical of European countries since the 17th century, when the Prussian lands invited Protestants from all over Europe, offering various preferences for immigrants.

Pensions in Latvia, Lithuania and Estonia are low, compared to Western European countries. Since 2001, a new approach to assignment of pensions has been implemented in the countries. The average pension is Euro 380 , which is actually one third less than the European average (Euro 1,140). The pension benefit situation is in many ways aggravated by a rapid ageing of the population. The average indicator for the Baltic States is $34 \%$ of senior citizens out of the total population, and this figure keeps growing by $2-3 \%$ every year. Note that this trend is typical for many European countries (Accrued-todate pension...URL).

In terms of personal enhancement of citizens, the EU membership is largely a positive phenomenon. This statement is supported by opportunities to travel in Europe, employment prospects in more prosperous countries and accessibility of European education and medicine.

To understand the attitude of the population to the membership in the European Union, we propose to examine the results of sociological surveys conducted by the Eurobarometer service in 2004 (at the EU accession) and 2018. Note that the survey in 2018 had no option "more positive than negative", there were three options offered: "positive", "neutral" and "negative" attitudes. The methodology of Eurobarometer surveys involves the polling of all age groups with the maximum regional coverage. For illustration purposes, the evaluation results are presented in the form of Charts 1-2.

An analysis of the results shows that essentially the attitude of the population did not changed much, the existing fluctuations do not significantly reduce the indicators of 2004 , both in terms of positive attitude and negative 
Chart 1. Attitude of the residents of Latvia, Lithuania and Estonia to the European Union Membership (May 2004) ${ }^{2}$

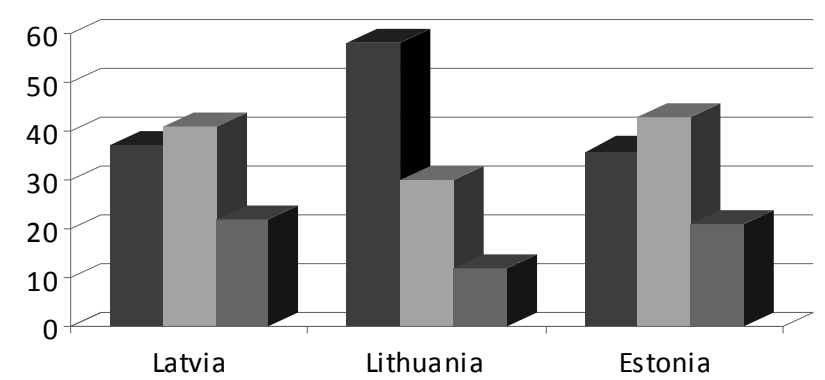

- Positive attitude

Positive rather than negative

Negative

Chart 2. Attitude of the residents of Latvia, Lithuania and Estonia to the European Union Membership (May 2018) ${ }^{3}$

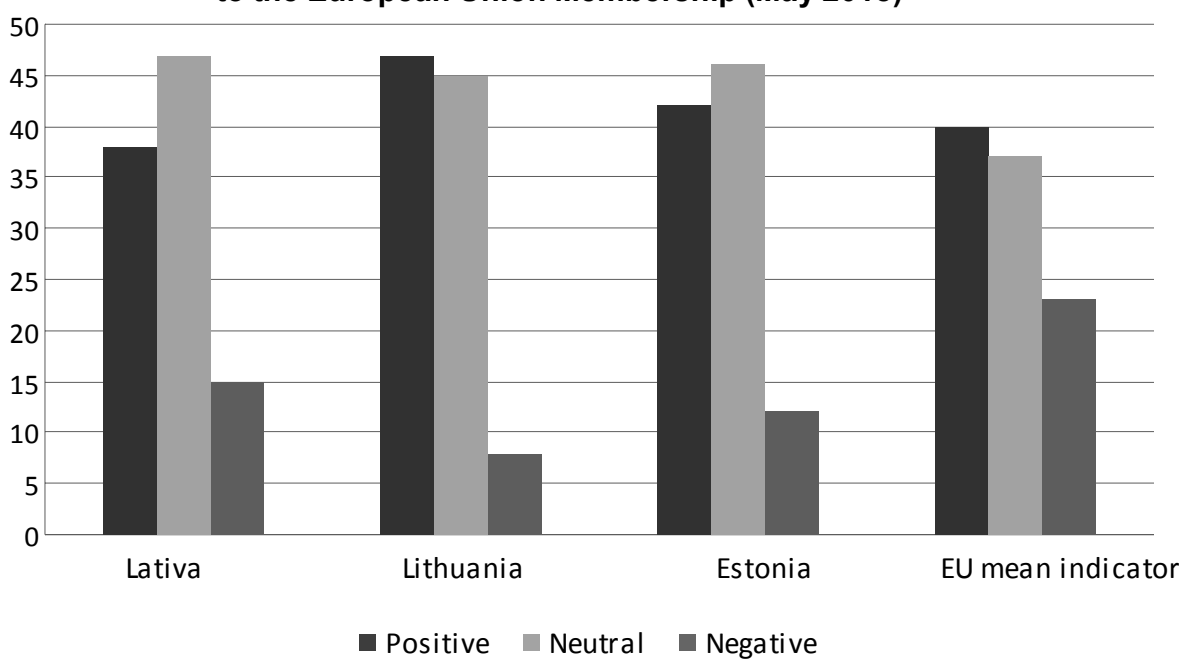

perception. Compared to the EU mean indicator, there are a lower percentage of negative attitude and a higher percentage of neutral attitude observed. In general, traditionally it is the population of Latvia, Lithuania and Estonia, which is more supportive of the idea of United Europe among the EU Member States.

The Baltic experience is topical for Ukraine in several dimensions. The first one is geopolitical. The expediency of the invariability of the Euro-Atlantic vector makes the country more attractive for investors. The security factor which is in fact a pass to a full EU membership necessitates serious political will as well as a consistent and clear compliance with NATO membership requirements.

The second dimension is legal. Adaptation of the acquis communautaire which is a key criterion for the EU membership requires a gradual approach and focusing of legislative activity on synchronization of the process with the EU. The complex of law, agreed upon with the EU, will contribute to an increase in investment and a shift in the attractiveness of the Ukrainian market.

The third dimension is economic. The scenario of economic development of the Baltic States implied the search for a development model in accordance with the capabilities of the economies. Identification of priority sectors in Ukraine with account of their competitiveness in the context of a joint market with the EU has to be balanced with interests of local elites. Under the conditions of low efficiency of industry, expensive energy resources and high energy consumption, most industries in Ukraine may not stand up to the competition of European manufacturers. Agriculture, on the contrary, subject to reasonable investment, may be competitive against even the most developed EU countries where soils have been already significantly worn out. In addition, given the experience of the Baltic States, the liberalization and simplification of the tax system is a major factor for the development of the economy and access of foreign companies.

It is necessary to assess a factor of the outflow of the population aged 25-35 years in Ukraine, which has gained in the scope over the recent 3 years. Creation of jobs and improvement of the infrastructure may largely halt the trend of the kind. Special attention has to be paid to rural areas and preservation of labor in this field.

\section{Conclusions}

24 years of the Baltic States' membership in the EU have passed under the slogan a "return to Europe". In the historical context, the countries have restored their inde-

\footnotetext{
2 Plotted by the authors, based on: Eurobarometer 2004.1. Public opinion in the acceding and candidate countries. Brussels: European Commission, 2004. 37 p.

${ }^{3}$ Plotted by the authors, based on: Standard Eurobarometer 89. Spring 2018. Brussels: European Commission. 2018. 44 p.
} 
pendence. By making European choice, Latvia, Lithuania and Estonia joined the most influential political and economic community in the world. The NATO membership, as a security factor, has become a safeguard against potential threats from Russia, which is, as seen from the Ukrainian experience, quite an important factor.

The process of integration into EU structures has significantly contributed to the internal development in all spheres of life. In economic terms, the specialization of the countries as attractive for investment has already become clear. The most developed industries are transport and services. A significant part of the industry has given way to the service and financial sectors because of noncompetitiveness. In comparison with the "old" EU members, economic indicators are below average but when compared with the former Soviet Republics, it is clear that the national indicators are three times better than in Ukraine, Georgia or Moldova. A positive fact is the growth dynamics of the economies of all three countries. The level of wages and pensions in the Baltic States is $30 \%$ lower at the mean than the EU average, which is typical of new entrants. Negative trends of European integration have significantly affected agriculture which accounts for about as little as $5 \%$ of the GDP.

The legal system of the Baltic States is as close as possible to European standards, which simplifies the coordination of and support to numerous joint economic projects.

The residents of the Baltic States have acquired good prospects in employment and education in EU countries, which, on the one hand, contributes to no further reproduction of the population whereas, on the other hand, offers new opportunities to people, making them more mobile and active in terms of choice of residence and selfrealization.

Taking into account the experience of the Baltic States by Ukraine at the present stage of cooperation with the EU has to result in modeling of an economic development scenario for the next 10 years, creating an attractive investment climate, improving energy efficiency, implementing projects aimed at raising living standards in order to prevent the outflow of the most economically active population aged 25 to 35 years.

\section{REFERENCES}

Bilonozhko, S. V., 2015. Western vector of the foreign policy of the Baltic countries: the path from independence to Eurointegration. Scientific works of the Historical Faculty of Zaporizhzhya National University. Vol. 44: 130-135 (ukr).

Vorotnikov, V. V., 2014. Baltic countries in NATO: the results of the decade. Herald of MGIMO-University. № 6: 9-17 (rus).

Zavadsky, V. M., 2008. European Integration of the Baltic States (1991-2004). These of Candidate of historical Science. Donetsk, 2008. 225 p. (ukr).

Kokoriev, O. V., 2016. Positive and negative consequences of transformation in the Baltic States and accession to the EU. Bulletin of Donetsk National University, Series: Political Sciences: 68-71 (ukr).

Pali, O. A. 2002. Specificity and implications of the integration of the Baltic States into Euro-Atlantic security structures. Scientific notes of NaUKMA. Vol. 20: 55-60 (ukr)

Accrued-to-date pension entitlements in social insurance. Available at: http://appsso.eurostat.ec.europa.eu/nui/show.do?dataset=nasa_10_pens1\&lang=en (Accessed: 18.11.2018).
Agenda 2000, Communication: Reinforcing the pre-accession strategy. Brussels: European Commission, 1997. 120 p.

Investment in the Baltic States - KPMG - Global. Available at: https://www.kpmg.de/docs/InvestmentBalticSeas.pdf (Accessed: 21.11.2018).

Pastore, G. 2011. Europeanization of Foreign Policy of the New Member States: The Case of Latvia. A collection of research papers in conjunction with the international conference "European Integration and Baltic Sea Region: Diversity and Perspectives", 26-27 September 2011 at the University of Latvia. Litvia. Riga: 59-70.

The World Factbook. Available at: https://www.cia.gov/library/ publications/the-world-factbook/fields/214.html\#LH (Accessed: 21.11.2018)

Total number of long-term emigrants leaving from the reporting country during the reference year. Available at: https:// ec.europa.eu/eurostat/tgm/table.do?tab=table\&init=1\&language=en\&pcode=tps00177\&plugin=1 (Accessed: 18.11.2018).

Wage and salaried workers. Available at: https://data.worldbank.org/indicator/ SL.EMP.WORK.MA.ZS?end=2017\&start=1991\&view=chart (Accessed: 21.11.2018).

\section{ВИКОРИСТАНІПОСИЛАННЯ}

Білоножко С. В. Західний вектор зовнішньої політики країн Балтії: шлях від незалежності до Євроінтеграції. Наукові праці історичного фракультету Запорізького національного університету. Запоріжжя, 2015. Вип. 44. С. 130-135.

Воротников В. В. Страны Балтии в НАТО: итоги десятилетия. Вестник МГИМО-Университета. Москва, 2014. № 6. С. 9-17.

Завадський В. М. Європейська інтеграція країн Балтії (1991-2004): дис. ... канд. іст. наук: 07.00.02 / Донецький. нац. ун-т. Донецьк, 2008. 225 с.

Кокорєв О. В. Позитивні і негативні наслідки трансформації в країнах Балтії та вступу до ЄС. Вісник Донецького національного університету, Серія: Політичні науки. Вінниця, 2016. С. 68-71.

Палій О. А. Специфіка та наслідки інтеграції країн Балтії до Євроатлантичних структур безпеки. Наукові записки НаУКМА. Київ, 2002. Том 20. С. 55-60.

Accrued-to-date pension entitlements in social insurance. URL: http://appsso.eurostat.ec.europa.eu/nui/show.do?dataset=nasa_10_pens1\&lang=en (дата звернення 18.11.2018).

Agenda 2000, Communication: Reinforcing the pre-accession strategy. Brussels: European Commission, 1997. 120 p.

Investment in the Baltic States - KPMG - Global. URL: https:// www.kpmg.de/docs/InvestmentBalticSeas.pdf (дата звернення 21.11.2018)

Pastore G. Europeanization of Foreign Policy of the New Member States: The Case of Latvia. A collection of research papers in conjunction with the international conference "European Integration and Baltic Sea Region: Diversity and Perspectives", 26-27 September 2011 at the University of Latvia. Litvia. Riga, 2011. P. 59-70.

The World Factbook. URL: https://www.cia.gov/library/ publications/the-world-factbook/fields/214.html\#LH (дата звернення 21.11.2018).

Total number of long-term emigrants leaving from the reporting country during the reference year. URL: https://ec.europa.eu/ eurostat $/$ tgm/table.do?tab=table\&init=1 \&language=en \&pcode=tps00177\&plugin=1 (дата звернення 18.11.2018).

Wage and salaried workers. URL: https:// data.worldbank.org/ indicator/SL.EMP.WORK.MA.ZS?end=2017\&start=1991\&view=chart (дата звернення 21.11.2018). 
Донай Лукаш,

Університет імені Адама Міџкевича у Познані (Польща),

e-mail: lukasz.donaj@amu.edu.pl, ORCID 0000-0002-7720-1260

Завадський Віталій,

Київський університет імені Бориса Грінченка (Украӥна),

e-mail:v.zavadskyi@kubg.edu.ua, ORCID 0000-0002-0384-5979

\section{5 РОКІВ ЧЛЕНСТВА КРАЇН БАЛТІЇ В ЄС: ПРОБЛЕМИ, ПЕРСПЕКТИВИ ТА ДОСВІД ДЛЯ УКРАЇНИ}

У статті висвітлені ключові положення дослідження результатів повноправного членства країн Балтії в Європейському Союзі. Аналізуючи геополітичний вимір європейського вибору, автори підготували стислий дискурс викликів, які виникли у часи відновлення незалежності Латвії, Литви та Естонії. Розглянуто чинники європейського вибору зазначених країн, які полягали в безпековому, економічному та соціальному вимірах.

Безпековий фактор європейського вектору політики актуалізувався у прагненні політичних еліт вивести країни зі сфери впливу Росії. В економічному плані країни прагнули переорієнтації економік на західні ринки та інкорпорації в архітектуру торговельних зв'язків розвинених країн Євросоюзу.

Зазначено, що завдяки євроатлантичному вектору зовнішньої політики та чіткому виконанню критеріїв членства, країни Балтії отримали доступ до пільгового кредитування, програм допомоги країнам-кандидатам й змогли сформувати один із найпривабливіших інвестиційних кліматів у Східній Європі.

За допомогою статистичних баз Світового банку, ресурсу "Євростат", аналітичних матеріалів провідної аудиторської компанії KPMG проаналізовано ключові економічні показники: динаміку ВВП (за ПкС) у порівнянні $з$ іншими країнами Центральної та Східної Європи, рівень заробітної плати та пенсійних виплат. Розгляд економічних здобутків від членства в $€$ доповнено аналізом структури ВВП та вивченням галузевої специфікації.

Визначено й втрати від процесу євроінтеграції, які полягали у: значному скороченні промислового виробництва, нерентабельності сільського господарства, еміграції населення у віці від 25 до 35 років.

Ставлення мешканців до членства країн в Євросоюзі вивчено із використанням результатів щорічних опитувань європейської служби "Євробарометр". 3'ясовано, що у 2018 році позитивне ставлення мешканців Латвії, Литви та Естонії фактично не змінилося порівняно з 2004 роком. Наявні у статті діаграми дозволяють також визначити, що рівень євроскептицизму у зазначених країнах значно не змінився у порівнянні 3 першим роком членства в $€$.

Авторами запропоновані алгоритми врахування Україною досвіду країн Балтії на шляху до повноправного членства.

Ключові слова: країни Балтії; ЄС; результати; членство; Україна; досвід.

(c) Донай Лукаш, Завадський Віталій

Надійшла до редакції: 10.12.2018

Прийнята до друку: 17.12.2018

СХІД № 6 (158) листопад-грудень 2018 р. 